\title{
Studies on the effect of vanillin (food additive) on some metabolic reactions of the experimental animals
}

\author{
By R. A. El-Massry, S. M. Labib, M. Z. Sitohy and S. S. El Saadany. \\ Zagazig Univ. College of Agric. Biochemistry Department \\ Zagazig, Egypt.
}

\begin{abstract}
RESUMEN
Estudio sobre el efecto de la vanillina (aditivo alimentario) en algunas reacciones metabólicas de animales experimentales.

Se administró vanillina (4-hidroxi-3-metoxibenzaldehido) a ratas albino hipercolesterolémicas en dosis bajas y altas $(1,0$ y $2,0 \%$ respectivamente) por un periodo de nueve semanas. La forma lipídica asi como las funciones hepáticas y renales se determinaron en ratas normales, hipercolesterolémicas e hipercolesterolémicas a las que se les administró vanillina. La hipercolesterolemia se caracterizó por un aumento significativo en los niveles medios de lípidos totales, colesterol total y triglicéridos, y una disminución significativa en el contenido de fosfolipidos. También, la función hepática (S.GOT, S.GPT, alcalina y ácido fosfatasa) así como las funciones renales se elevaron en comparación con el grupo control. La administración de vanillina redujo significativamente los lípidos totales de hígado y riñones. El bazo y corazón siguieron la misma tendencia pero con efecto moderado, mientras que el cerebro no se afectó.

El colesterol total en hígado, riñones, bazo y corazón disminuyó significativamente, en tanto que en cerebro no se afectó.

Los triglicéridos disminuyeron significativamente en higado y bazo, mientras que no se alteraron en riñones y cerebro.

También hubo una disminución significativa en la alta actividad de S.GOT, S.GPT, alcalina y fosfatasa ácida y se alcanzaron valores muy próximos al nivel inicial. La administración de vanillina ejerció efectos anabólicos potentes para el metabolismo de proteinas como se demuestra de los resultados del ácido urónico y creatinina.

PALABRAS-CLAVE: Aditivo alimentario - Rata - Reacción metabólica - Vanillina (efecto de).
\end{abstract}

\section{SUMMARY}

Studies on the effect of vanillin (food additive) on some metabolic reactions of the experimental animals.

Vanillin (4-hydroxy-3-methoxybenzaldehyde) was administrated to hypercholesterolemic albino rats at low and high doses (1.0 and $2.0 \%$, respectively) for nine weeks period. Lipid pattern, as well as liver and kidneys functions were determined in normal, hypercholesterolemic and hypercholesterolemic rats ad ministrated vanillin. Hypercholesterolemia was characterized by significant increase in the average levels of total lipids, total cholesterol and triglycerides and a significant decrease in phospholipids content. Also, liver function (S.GOT, S.GPT, alkaline and acid phosphatase) as well as kidneys function were eleva- ted compared to control group. Administration of vanillin significantly reduced liver and kidneys total lipids. Spleen and heart followed nearly the same trend but with moderate effect, while brain was not affected. Liver, kidneys, spleen and heart total cholesterol was significantly reduced while brain total cholesterol was not affected. Triglycerides were significantly decreased in liver and spleen, while that of kidneys and brain was not affected. Also, there was a significant decrease in the high activity of S.GOT, S.GPT, alkaline and acid phosphatase and the values were nearly attained to the initial level. Administration of vanillin exertes potent anabolic effects for protein metabolism as shown from the results of uric acid and creatinine.

KEY-WORDS: Food additive - Metabolic reactions - Rat Vanillin (effect of).

\section{INTRODUCTION}

Cholesterol presents a great health hazard when its consumption is unduely increased. Hyperlipaemia is a gross derangement in metabolism starting from the rare hereditary hypercholesterolemia up to the widespread adult condition. Hypercholesterolemic arteriopathies whether coronary or cerebral take the bigest tool of middle aged and elderly deaths (1). Regarding the etiological factors of hypercholesterolemia, this syndrome still remains to be dealt with as a biochemical entity in a trial to correct it as well as to judge for the success or failure of the medications used as thereapeutic agents. Nowadays, biochemists, pharmacologists and physicians, among other investigators are always looking for more effective hypocholesterolemic agents. Although some of their results may prove to be satisfactory, yet the uttery successful medicament has not been discovered. The present work is an attempt to evaluate the potency of vanillin as hypocholesterolemic agent in the treatment of hypercholesterolemic rats. It was intended that the results of these studies well aid in the selection of new sources which combines the efficiency and safety in the treatment of hypercholesterolemia and hyperlipaemia. 


\section{MATERIALS AND METHODS}

\subsection{Material}

Vanillin, (4-hydroxy-3-methoxy benzaldehyde) was obtained from Aldrich Chem. Company, Inc. USA.

\subsection{Animals, Diets and Treatments}

A total of ninety six, 60 days old male albino rats weighing $100-120 \mathrm{~g}$ were kept under normal healthy laboratory conditions and fed normal diet which consisted of casein $15 \%$, cotton seed oil $10 \%$; cellulose $5 \%$, salt mixture $4 \%$ (Hegested et al. (2)), vitamin mixture 1\% (Campbell, (3)) and corn starch $65 \%$ ad libitum for two weeks (adaptation period). The animals were divided randomly into two groups. Animals in group I (24 rats) were continued feeding on the basal diet and served as negative control. Animals in group 11 (72 rats) were subjected to a hypercholesterolemic regime for a period of 12 weeks. Induction of hypercholesterolemia in the experimental animals was employed using the method of Abdel-Raheim et al. (4) using cholesterol and choleic acid mixture. During this period, blood samples from the individual rats were collected via the puncture of retobulber venous plexus by a fine cappillary glass tube every three weeks to determine the levels of all lipid fractions to achieve hypercholesterilemia. After this period the hypercholesterolemic rats were divided into three subgroups II a, II b and II c. Rats in subgroup II a was continued feeding on the hypercholesterolemic regimen and served as hypercholesterolemic control (positive control). Rats in the other two subgroups were also continued feeding on hypercholesterolemic regimen but were administrated low and high dose of vanillin $(1.0$ and $2.0 \%$ respectively at the expense of starch) for a period of nine weeks and every three weeks six rats of each group or subgroup were killed by decapitation. Blood, liver, kidnyes, brain, spleen and heart were removed and chilled for further processes.

\subsection{Enzymes and metabolits assays}

Total lipids, total cholesterol, triglycerides and phospholipids, in all studied organs were determined according to Knight et al. (5), Chaurchami et al. (6), Fletcher (7) and Bartlett (8), respectively. Total free amino acids were determined according to Lee and Takabashi (9). Serum glutamate-pyruvate and glutamate oxaloacetate transaminases (S. GPT and S. GOT) (Ritman and Frankel, (10)). Alkaline phosphatase (King and King, (11)), total serum protein (Lowary et al., (12)), serum albumin and globulin (Peter, (13)) serum uric acid (Caraway, (14)) creatinine (Chasson et al., (15)) statistical analysis [t-test (Snedechor and Cochran (16))]. All the procedures were determined routinelly according to the methods in brackets.

\section{RESULTS AND DISCUSSION}

In the present investigation the induction of hypercholesterolemia in the experimental animals was the first practical objective in order to evaluate the response of lipid pattern to Vanillin induction. The level of normal lipid pattern of rats used in the present study was evaluated prior to the initiation of the experiment and after the induction of hypercholesterolemia and then after administrating Vanillin at $1 \%$ and $2 \%$ doses at the expense of starch for nine weeks period and the results are given in Tables I, II and III.

Data in Table I indicated that the average level of blood total lipids was elevated from 326 to 815 $\mathrm{mg} / \mathrm{dL}$ after 12 weeks of administrating of the hypercholesterolemic mixture and to $922 \mathrm{mg} / \mathrm{dL}$ at the end of the experimental period (21 weeks). Blood cholesterol represents the main item under investigation. The pre experimental level was 116.11 and the final level was $280.6 \mathrm{mg} / \mathrm{dL}$ after 12 weeks of administration of the hypercholesterolemic mixture. Another conspicuous level of $385.2 \mathrm{mg} / \mathrm{dL}$ was attained after 21 weeks in the cholesterol loaded animals. The triglyceride level showed a regular rise from the normal value of 44.6 to 184.6 $\mathrm{mg} / \mathrm{dL}$ after 12 weeks, and to $235.9 \mathrm{mg} / \mathrm{dL}$ after 21 weeks feeding of hypercholesterolemic diet. It is stated that triglycerides represent a synchronous rise with that of cholesterol, Boxer, et al. (17). Also, data in Table I demonstrated that there was a progressive decline in the level of blood phospholipids from initial value of $118.6 \mathrm{mg} / \mathrm{dL}$ to $82.6 \mathrm{mg} / \mathrm{dL}$ after 12 weeks of the start of experiment. The phospholipids hepatic storage in hypercholesterolemia seem to be the factor involved in the progressive decline in blood phospholipids, Tawfic (18). As shown in Table I administration of Vanillin showed a marked progress in the correction of lipid cholesterol complex, in spite of the continued cholesterol loading during the treatment. After nine weeks of treatment with Vanillin, the level of serum total lipids was declined from 922 to 470 and $415 \mathrm{mg} /$ 
dL. The cholesterol level decreased from 385.2 to 161.7 and $146.5 \mathrm{mg} / \mathrm{dL}$. It appears that the average level of triglycerides which amounted to 235.9 $\mathrm{mg} / \mathrm{dL}$ in the pretreatment level was lowered to 84.2 and $81.4 \mathrm{mg} / \mathrm{dL}$. The level of phospholipids, however was increased from 42.0 to 98.6 and 102.5 respectively.

The administration of cholesterol and cholic acid mixture during the treatment with Vanillin was carried out primarily in order to abolish the possibility of self curing after the withdrawlal of these drugs. It is also well established that hypercholesterolemia in human is a combination of a dietary and endogenous factors in lipid metabolism. Therefore the state continuous in human during the treatment with the hypocholesterolemic agent, the continuation of cholesterol administration in therefore closer to the natural state of events.

The effect of vanillin on the lipid pattern was also studied in the different rat organs before and after treatment. As shown in Tables I, II and III there were some rises of all lipids fractions of the normal rats. This may be due to life span of the rats which is extremely short, so the age of rats may be a factor affecting the results especially if we consider that the experimental period lasted for 21 weeks. On the other hand hypercholesterolemia was characterized by significant increase in the average levels of total lipids, total cholesterol and triglycerides and a significant decrease in phospholipids as compared with the corresponding values of the untreated rats. Total lipids in liver was significantly increased compared with negative control during the induction period. Total lipids in brain, kidneys and spleen was not affected, while that of heart was slightly increased. Triglycerides also, showed a high significant increase in liver and kidneys while that of heart was slightly increased but in brain was not affected. Total cholesterol in liver, brain kidneys, spleen and heart was significantly increased upon administrating mixture of cholesterol and cholic acid. The liver was characterized by high cholesterol content. The hypercholesterolemic state was associated with a general decrease in liver and kidneys phospholipids, while that of brain was nearly unaffected. These results concerning hypercholesterolemic state are in agreement with Said (19) and El-Saadany et al., (2021).

The value of administrating Vanillin in low and high doses (1.0 and $2.0 \%$, respectively at the expense of starch) to hypercholesterolemic rats show that, Vanillin significantly reduced, liver and kidneys total lipids. Total lipids in spleen and heart followed the same trend but with moderate effect while that of brain was not affected. Liver, kidney, spleen and heart total cholesterol was significantly reduced, while that of brain was also not affected, despite the continued cholesterol and cholic acid loading. Triglycerides also were significantly decreased in liver and spleen and slightly. decreased in the heart while that of kidneys and brain was not affected by Vanillin administration. Triglycerides are normally formed by single esterification of circulating fatty acids from adipose tissues and newly produced fatty acids rived from dietary sources. The increase in triglycerides levels thus may be due to either the increase of lipogenesis process or to the decrease in its removal from plasma to impairement of lipoprotein activity. The latter case has been formed to decline after administration of Vanillin in both low or high doses. The obtained results are similar with that obtained by Abdel-Rheim, et al. (4) and El-Saadany et al., (20-21) who studied the hypocholesterolemic effect of Balanetus aegyptica fruits, Karkade and Cassia fistula, respectively, on hypercholesterolemic albino rats. The hypocholesterolemic action of Vanillin may be due to the phenolic structure of such compound.

To study safety of such compound to be used as food additive, liver function as well as kidneys function were determined before, during and after administration (every three weeks) and the results are given in Tables IV, V and VI.

As shown in Table IV hypercholesterolemia was characterized by significant increase in G P T. The increase attained about 1.5 fold that of normal rats. The increase of acid phosphatase was more pronounced than that of alkaline phosphatase. Also, its effect on $G P T$ was more pronunced than that of GOT. The increase in GPT activity indicate liver cell necrosis. The increase of GOT activity was less specific for hepatic injury. These results are in agreement with those obtained by El-Saadany et al. (20-21).

Increasing the activity of transaminase may stem from the second amino group of urea which enters the urea cycle arriving in the form of aspartate: GOT play a remarkable role as shown:

Glutamic + Oxalacetic $\stackrel{\text { GOT }}{\longrightarrow} \alpha$-Ketoglutaric + aspartate

The amino group of aspartate condeses with the carbonyl carbon atom of citruline in the presence of ATP, to form argininosuccinate which reversibly cleaved by argininosuccinase to form arginine and fumarate. Fumarate and $\alpha$-Ketoglutarate formed return to the pool of tricarboxylic acid cycle (TCA) intermediates. Also, the production of $\alpha$-Ketoglutaric acid was stimulated by increasing 
Table I : Effect of administrating Vaniline on serum and liver lipids pattern of hypercholesterolemic rats.

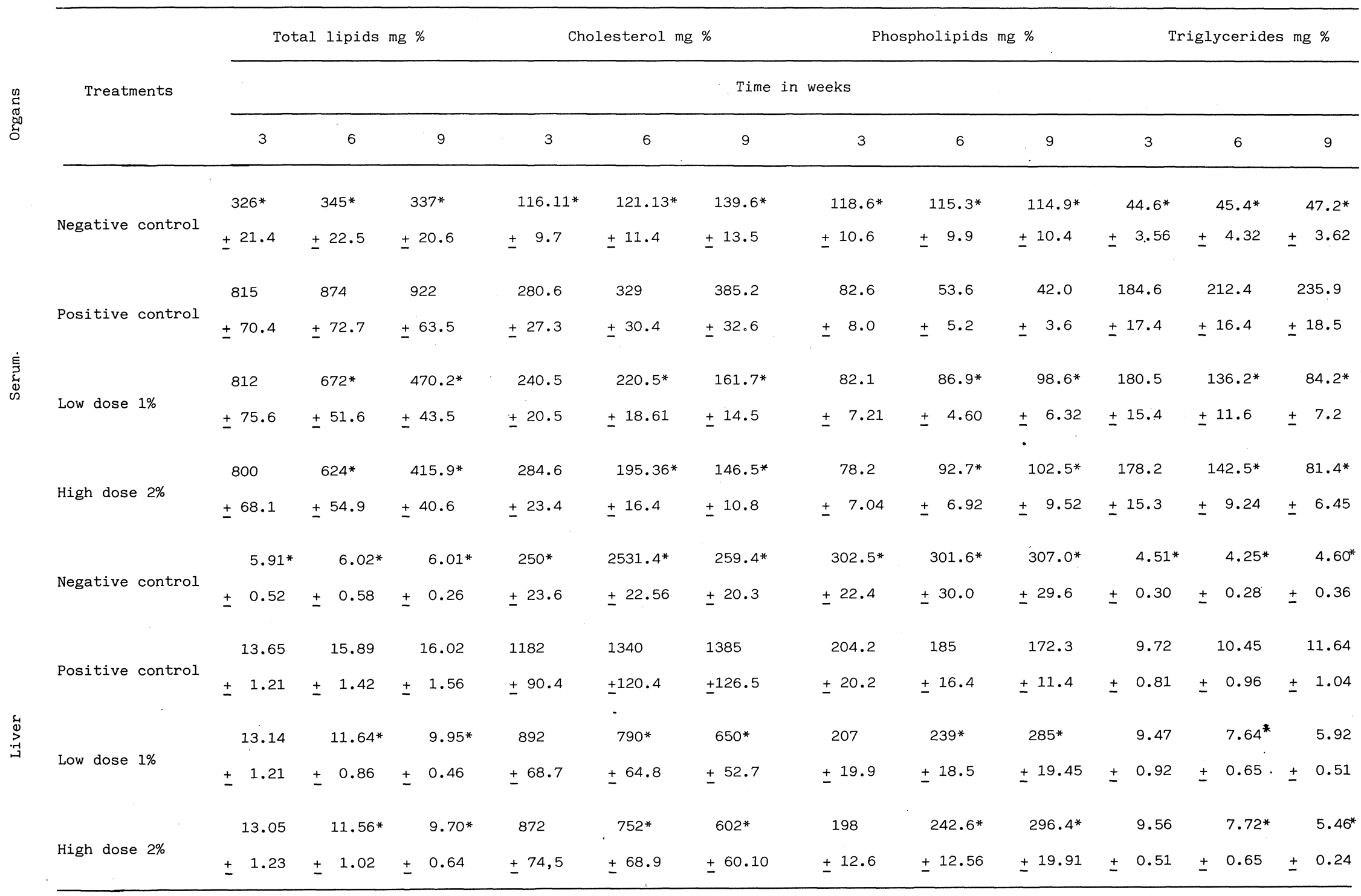

*Values are significant relative to positive control $(\mathrm{P}<0.01)$.

In liver total lipids and triglycerides are expressed as $\mathrm{g} . / 100 \mathrm{~g}$. 
Table II : Effect of administrating Vaniline on kidneys and brain lipids pattern of hypercholesterolemic rats.

\begin{tabular}{|c|c|c|c|c|c|c|c|c|c|c|c|c|}
\hline \multirow{3}{*}{ Treatments } & \multicolumn{3}{|c|}{$\begin{array}{l}\text { Total lipids } \\
\mathrm{gm} / 100 \mathrm{gm}\end{array}$} & \multicolumn{3}{|c|}{ Cholesterol mg/100 gm } & \multicolumn{3}{|c|}{ Phospholipids mg/100 gm } & \multicolumn{3}{|c|}{$\begin{array}{l}\text { Triglyceride } \\
\text { gm/100 gm }\end{array}$} \\
\hline & \multicolumn{12}{|c|}{ Time in weeks } \\
\hline & 3 & 6 & 9 & 3 & 6 & 9 & 3 & 6 & 9 & 3 & 6 & 9 \\
\hline \multirow{2}{*}{ Negative control } & 8.92 & 8.98 & 9.14 & $445^{*}$ & $452 *$ & $464^{*}$ & 1030 & 1046 & 1022 & 7.18 & 7.24 & 7.35 \\
\hline & \pm 0.54 & \pm 0.86 & \pm 0.89 & \pm 36.4 & \pm 41.6 & \pm 42.4 & \pm 102.5 & \pm 79.4 & \pm 92.4 & \pm 0.69 & \pm 0.35 & \pm 0.45 \\
\hline \multirow{2}{*}{ Positive control } & 9.14 & 9.50 & 9.71 & 1082 & 1165 & 1239 & 976.4 & 932.5 & 854.4 & 7.44 & 7.64 & 7.88 \\
\hline & \pm 0.48 & \pm 0.45 & \pm 0.56 & \pm 104.2 & \pm 115.3 & \pm 120.5 & \pm 90.5 & \pm 91.6 & \pm 73.6 & \pm 0.69 & \pm 0.75 & \pm 0.78 \\
\hline \multirow{2}{*}{ Low dose $1 \%$} & 8.57 & 8.75 & 8.20 & 1072 & $892 *$ & 630 & 982.4 & 995.4 & 1024 & 7.36 & 7.24 & 7.20 \\
\hline & \pm 0.72 & \pm 0.87 & \pm 0.64 & \pm 98.6 & \pm 82.6 & \pm 61.4 & \pm 91.6 & \pm 82.4 & \pm 101.3 & \pm 0.49 & \pm 0.43 & \pm 0.65 \\
\hline \multirow{2}{*}{ High dose $2 \%$} & 8.75 & 8.57 & $8.00^{*}$ & 1056 & $742 *$ & $592 *$ & 996 & 1010 & 1021 & 7.36 & 7.28 & 7.12 \\
\hline & \pm 0.40 & \pm 0.82 & \pm 0.70 & \pm 90.2 & \pm 71.6 & \pm 52.4 & \pm 90.6 & \pm 88.4 & \pm 101.6 & \pm 0.72 & \pm 0.64 & \pm 0.61 \\
\hline \multirow{2}{*}{ Negative control } & 9.60 & 9.72 & 9.45 & 2540 & 2546 & 2565 & 1905 & 1924 & 1972 & 6.43 & 6.42 & 6.16 \\
\hline & \pm 0.56 & \pm 0.64 & \pm 0.35 & \pm 195 & \pm 178 & \pm 220.4 & \pm 181.6 & \pm 135.7 & \pm 182.6 & \pm 0.43 & \pm 0.58 & \pm 0.60 \\
\hline \multirow{2}{*}{ Positive control } & 9.56 & 9.78 & 9.70 & 2560 & 2520 & 2573 & 1908 & 1936 & 1942 & 6.40 & 6.37 & 6.32 \\
\hline & \pm 0.92 & \pm 0.90 & \pm 0.95 & \pm 208 & \pm 236.1 & \pm 226.2 & \pm 162.4 & \pm 185.3 & \pm 139.1 & \pm 0.52 & \pm 0.59 & \pm 0.53 \\
\hline \multirow{2}{*}{ Low dose $1 \%$} & 9.46 & 9.27 & 9.45 & 2510 & 2542 & 2545 & 1928 & 1964 & 1943 & 6.25 & 6.43 & 6.56 \\
\hline & \pm 0.46 & \pm 0.73 & \pm 0.62 & \pm 242.6 & \pm 195.4 & \pm 186.0 & \pm 179.5 & \pm 175.6 & \pm 164.6 & \pm 0.42 & \pm 0.32 & \pm 0.43 \\
\hline \multirow{2}{*}{ High dose $2 \%$} & 9.49 & 9.62 & 9.80 & 2570 & 2542 & 2562 & 1946 & 1952 & 1956 & 6.42 & 6.36 & 6.34 \\
\hline & \pm 0.94 & \pm 0.56 & \pm 0.64 & \pm 212.0 & \pm 206 & \pm 252.4 & \pm 175.4 & \pm 185.4 & \pm 170.4 & \pm 0.42 & \pm 0.56 & \pm 0.62 \\
\hline
\end{tabular}

* Values are significant relative to positive control $(\mathrm{P}<0.01)$ 
Table III: Effect of administrating vaniline on spleen and heart lipids pattern of hypercholesterolemic rats.

\begin{tabular}{|c|c|c|c|c|c|c|c|c|c|c|c|c|}
\hline \multirow{3}{*}{ Treatments } & \multicolumn{3}{|c|}{$\begin{array}{l}\text { Total lipids } \\
\mathrm{gm} / 100 \mathrm{gm}\end{array}$} & \multicolumn{3}{|c|}{$\begin{array}{c}\text { Cholesterol } \\
\mathrm{mg} / 100 \mathrm{gm}\end{array}$} & \multicolumn{3}{|c|}{$\begin{array}{l}\text { Phospholipids } \\
\mathrm{mg} / 100 \mathrm{gm}\end{array}$} & \multicolumn{3}{|c|}{$\begin{array}{l}\text { Triglyceride } \\
\text { gm/100 gm }\end{array}$} \\
\hline & \multicolumn{12}{|c|}{ Time in weeks } \\
\hline & 3 & 6 & 9 & 3 & 6 & 9 & 3 & 6 & 9 & 3 & 6 & 9 \\
\hline \multirow{2}{*}{ Negative control } & 2.35 & 2.36 & 2.46 & $122 *$ & $143^{*}$ & $162^{*}$ & 812 & 835 & 866 & 1.64 & 1.68 & $1.60 *$ \\
\hline & \pm 0.21 & \pm 0.23 & \pm 0.24 & \pm 7.5 & \pm 13.5 & \pm 14.6 & \pm 66.4 & \pm 75.6 & \pm 80.4 & \pm 0.11 & \pm 0.14 & \pm 0.13 \\
\hline \multirow{2}{*}{ Positive control } & 2.64 & 2.86 & 3.12 & 325 & 382.5 & 405.6 & 784 & 732 & 714 & 1.77 & 1.92 & 2.08 \\
\hline & \pm 0.23 & \pm 0.25 & \pm 0.31 & \pm 29.4 & \pm 20.5 & \pm 32.5 & \pm 61.4 & \pm 71.2 & \pm 70.2 & \pm 0.16 & \pm 0.19 & \pm 0.20 \\
\hline \multirow{2}{*}{ Low dose $1 \%$} & 2.56 & 2.55 & 2.52 & 310.2 & $262.0^{*}$ & $242 *$ & 762 & 784 & 812 & 1.72 & 1.72 & $1.62 *$ \\
\hline & \pm 0.24 & \pm 0.20 & \pm 0.21 & \pm 28.5 & \pm 21.6 & \pm 20.6 & \pm 53.5 & \pm 62.4 & \pm 80.3 & \pm 0.16 & \pm 0.14 & \pm 0.11 \\
\hline \multirow{2}{*}{ High dose $2 \%$} & 2.64 & 2.56 & 2.48 & 316.4 & $265 *$ & $230 *$ & 792 & 799 & 798 & 1.82 & 1.68 & $1.63^{*}$ \\
\hline & \pm 0.25 & \pm 0.25 & \pm 0.20 & \pm 25.6 & \pm 21.9 & \pm 16.4 & \pm 49.6 & \pm 45.6 & \pm 78.4 & \pm 0.18 & \pm 0.14 & \pm 0.16 \\
\hline \multirow{2}{*}{ Negative control } & 1.32 & 1.28 & 1.38 & 132 & $138 *$ & $149 *$ & 280 & $296^{*}$ & $315 *$ & 0.89 & $0.95 *$ & $1.05 *$ \\
\hline & \pm 0.11 & \pm 0.09 & \pm 0.12 & \pm 12.4 & \pm 11.6 & \pm 13.5 & \pm 22.4 & \pm 26.2 & \pm 30.2 & \pm 0.08 & \pm 0.07 & \pm 0.10 \\
\hline \multirow{2}{*}{ Positive control } & 1.48 & 1.56 & 1.84 & 218.5 & 239 & 256 & 246.5 & 224.6 & 210 & 1.20 & 1.24 & 1.42 \\
\hline & \pm 0.13 & \pm 0.10 & \pm 0.18 & \pm 20.4 & \pm 20.4 & \pm 20.5 & \pm 23.6 & \pm 20.5 & \pm 19.4 & \pm 0.10 & \pm 0.11 & \pm 0.13 \\
\hline \multirow{2}{*}{ Low dose $1 \%$} & 1.56 & 1.52 & $1.43^{*}$ & 212.5 & $180.5^{*}$ & $173.6^{*}$ & 254 & 264 & $268^{*}$ & 1.16 & 1.09 & $1.06^{*}$ \\
\hline & \pm 0.14 & \pm 0.13 & \pm 0.10 & \pm 16.5 & \pm 16.4 & \pm 16.4 & \pm 20.5 & \pm 16.3 & \pm 18.4 & \pm 0.09 & \pm 0.10 & \pm 0.10 \\
\hline \multirow{2}{*}{ High dose $2 \%$} & 1.54 & 1.46 & $1.44^{*}$ & 206.4 & $190.4 *$ & $168.6^{*}$ & 248 & 258 & $272^{*}$ & $1.16^{\circ}$ & 1.08 & $1.04^{*}$ \\
\hline & \pm 0.14 & \pm 0.11 & \pm 0.13 & \pm 13.5 & \pm 17.3 & \pm 14.4 & \pm 22.3 & \pm 23.0 & \pm 24.6 & \pm 0.13 & \pm 0.08 & \pm 0.09 \\
\hline
\end{tabular}

* Values are significant relative to positive control $(\mathrm{P}<0.01)$. 


\begin{tabular}{|c|c|c|c|c|c|c|c|c|c|c|c|c|c|c|c|}
\hline \multirow{2}{*}{ Treatments } & \multirow{2}{*}{\multicolumn{3}{|c|}{$\begin{array}{c}\text { Acid phos. } \\
\text { K.A. units/L. }\end{array}$}} & \multirow{2}{*}{\multicolumn{3}{|c|}{$\begin{array}{c}\text { Alk. phos. } \\
\text { K.A. units/L. }\end{array}$}} & \multicolumn{3}{|c|}{ GOT } & \multirow{2}{*}{\multicolumn{3}{|c|}{ serum }} & \multirow{2}{*}{3} & \multirow[b]{2}{*}{ GOT/GPT } & \multirow{2}{*}{9} \\
\hline & & & & & & & \multicolumn{3}{|c|}{ Mg pyruric acid/ml. serum } & & & & & & \\
\hline Negative & $682^{*}$ & $6.99 *$ & $7.30^{*}$ & 28.6 & $28.9^{*}$ & $29.5^{*}$ & 49.50 & $48.62 *$ & $51.60 *$ & $21.56^{*}$ & $20.82 *$ & $21.08^{*}$ & 2.29 & 2.34 & 2.45 \\
\hline control & \pm 0.54 & \pm 0.69 & \pm 0.72 & \pm 2.64 & \pm 2.74 & \pm 2.54 & \pm 3.95 & \pm 4.26 & \pm 4.82 & \pm 2.16 & \pm 1.64 & \pm 1.82 & \pm 0.181 & \pm 0.23 & \pm 0.16 \\
\hline Positive & 8.52 & 9.98 & 11.82 & 35.62 & 35.89 & 38.99 & 68.6 & 69.70 & 79.82 & 27.56 & 29.52 & 31.6 & 2.48 & 2.36 & 2.52 \\
\hline control & \pm 0.74 & \pm 0.86 & \pm 1.15 & \pm 3.16 & \pm 3.21 & \pm 2.93 & \pm 6.2 & \pm 5.42 & \pm 7.82 & \pm 2.62 & \pm 2.16 & \pm 3.01 & \pm 0.81 & \pm 0.16 & \pm 0.24 \\
\hline Low dose & 8.92 & 8.77 & $7.50 *$ & 38.50 & 34.60 & $31.62^{*}$ & 65.60 & 61.40 & $58.6^{*}$ & 27.56 & 26.56 & $26.02^{*}$ & 2.38 & 2.31 & 2.25 \\
\hline $1 \%$ & \pm 0.87 & \pm 0.82 & \pm 0.72 & \pm 3.32 & \pm 3.16 & \pm 3.01 & \pm 4.35 & \pm 5.21 & \pm 5.42 & \pm 2.07 & \pm 1.8 & \pm 1.64 & \pm 0.26 & \pm 0.91 & \pm 0.19 \\
\hline High dose & 9.05 & $7.25 *$ & $6.50 *$ & 34.64 & 32.76 & $30.56^{*}$ & 64.30 & 60.8 & $59.50 *$ & 26.60 & $24.06^{*}$ & $24.65^{*}$ & 2.42 & 2.53 & 2.41 \\
\hline $2 \%$ & \pm 0.89 & \pm 0.62 & \pm 0.62 & \pm 3.31 & \pm 3.16 & \pm 2.7 & \pm 3.62 & \pm 4.35 & \pm 4.32 & \pm 1.86 & \pm 2.35 & \pm 1.65 & \pm 0.20 & \pm 0.18 & \pm 0.18 \\
\hline
\end{tabular}

* Values are significant relative to positive control $(P<0.01)$.

Table V: Effect of administrating Vanillin on serum protein fraction and free amino acids of hypercholesterolemic rats.

\begin{tabular}{|c|c|c|c|c|c|c|c|c|c|c|c|c|c|c|c|}
\hline \multirow{3}{*}{ Treatments } & \multicolumn{3}{|c|}{ Protein $\mathrm{gm} / \mathrm{dl}$} & \multicolumn{3}{|c|}{ Albumin gm/dl } & \multicolumn{3}{|c|}{ Globulin gm/dl } & \multicolumn{3}{|c|}{ Alb./ Glub } & \multicolumn{3}{|c|}{ Free amino acid $\mathrm{Mg} / \mathrm{dl}$} \\
\hline & \multicolumn{15}{|c|}{ Time in weeks } \\
\hline & 3 & 6 & 9 & 3 & 6 & 9 & 3 & 6 & 9 & 3 & 6 & 9 & 3 & 6 & 9 \\
\hline Negative & $7.16^{*}$ & $7.45^{*}$ & $7.56^{*}$ & 4.25 & $4.35^{\circ}$ & 4.25 & $2.91 *$ & $3.20 *$ & $3.31 *$ & $1.55^{*}$ & $1.36 *$ & $1.28^{*}$ & $87.2^{*}$ & $77.6^{*}$ & $80.2^{*}$ \\
\hline control & \pm 0.62 & \pm 0.71 & \pm 0.52 & \pm 0.42 & \pm 0.37 & \pm 0.36 & \pm 0.26 & \pm 0.28 & \pm 0.31 & \pm 0.12 & \pm 0.11 & \pm 0.08 & \pm 7.2 & \pm 7.0 & \pm 5.6 \\
\hline Positive & 9.02 & 9.82 & 10.20 & 4.65 & 4.85 & 4.92 & 4.37 & 4.97 & 5.28 & 1.06 & 0.98 & 0.93 & 108.40 & 108.5 & 104.5 \\
\hline control & \pm 0.45 & \pm 0.92 & \pm 0.64 & \pm 0.38 & \pm 0.32 & \pm 0.35 & \pm 0.41 & \pm 0.48 & \pm 0.35 & \pm 0.09 & \pm 0.06 & \pm 0.08 & \pm 9.5 & \pm 9.3 & \pm 8.5 \\
\hline Low dose & 8.98 & 8.56 & $8.15^{*}$ & 4.75 & 4.62 & 4.32 & 4.83 & $3.94^{*}$ & $3.83^{*}$ & 0.98 & 1.17 & $1.13^{*}$ & 108.0 & $88.2^{*}$ & $75.0 *$ \\
\hline $1 \%$ & \pm 0.43 & \pm 0.43 & \pm 0.78 & \pm 0.26 & \pm 0.26 & \pm 0.32 & \pm 0.42 & \pm 0.32 & \pm 0.26 & \pm 0.07 & \pm 0.08 & \pm 0.07 & \pm 9.6 & \pm 8.6 & \pm 7.2 \\
\hline High dose & 8.75 & 8.45 & $8.04 *$ & 4.82 & 4.75 & 4.28 & 3.93 & $3.70^{*}$ & $3.76^{*}$ & 1.26 & 1.28 & 1.14. & 99.60 & $84.4^{*}$ & $72.3^{*}$ \\
\hline $2 \%$ & \pm 0.52 & \pm 0.56 & \pm 0.64 & \pm 0.38 & \pm 0.42 & \pm 0.42 & \pm 0.16 & \pm 0.23 & \pm 0.32 & \pm 0.09 & \pm 0.09 & \pm 0.09 & \pm 8.7 & \pm 7.4 & \pm 6.3 \\
\hline
\end{tabular}


Table VI Effect of administrating Vaniline on kidney function of hypercholesterolemic rats.

\begin{tabular}{|c|c|c|c|c|c|c|}
\hline \multirow{3}{*}{ Treatments } & \multicolumn{3}{|c|}{ Creatinine (mg/dl) } & \multicolumn{2}{|c|}{ Uric acid (mg/dl) } & \\
\hline & \multicolumn{6}{|c|}{ Time in weeks } \\
\hline & 3 & 6 & 9 & 3 & 6 & 9 \\
\hline \multirow{2}{*}{ Negative control } & $0.88^{*}$ & $0.92 *$ & $0.95^{*}$ & 5.56 & 5.68 & 5.82 \\
\hline & \pm 0.011 & \pm 0.011 & \pm 0.012 & \pm 0.42 & \pm 0.55 & \pm 0.51 \\
\hline \multirow{2}{*}{ Positive control } & 1.10 & 1.20 & 1.23 & 6.08 & 6.21 & 6.18 \\
\hline & \pm 0.012 & \pm 0.012 & \pm 0.012 & \pm 0.35 & \pm 0.43 & \pm 0.60 \\
\hline \multirow{2}{*}{ Low dose $1 \%$} & 1.05 & $1.00 *$ & $0.98 *$ & 6.12 & 5.98 & 5.80 \\
\hline & \pm 0.013 & \pm 0.11 & \pm 0.010 & \pm 0.43 & \pm 0.52 & \pm 0.43 \\
\hline \multirow{2}{*}{ High dose $2 \%$} & 1.08 & $1.02 *$ & $0.96 *$ & 6.07 & 5.70 & 5.90 \\
\hline & \pm 0.012 & \pm 0.014 & \pm 0.01 & \pm 0.58 & \pm 0.54 & \pm 0.58 \\
\hline
\end{tabular}

* Values are significant relative to positive control ( $\mathrm{P}<0.01)$.

GPT activity. Fumaric and $\alpha$-Ketoglutaric acids (intermediates of TCA) are converted to citrate. The latter substance is cleaved to oxalacetate and acetyl COA which serves as a precursor for lipid biosynthesis.

Treatment with Vanillin induced a significant decrease in the high activity of GPT, GOT, alkalin and acid phosphatase and the values were nearly attained to the initial level (negative control) after nine weeks of administration. The present study indicated that the administration of Vanillin might alter (improves) the activity of liver function enzymes followed by changes in overall protein metabolism. Accordingly, some of the absorbed amino acids were deaminated and the amino nitrogen excreted as urea. On this basis, a relation might exist between protein metabolism and the increased body fat content.

Total serum protein, albumin, globulin and free amino acids of normal, hyper, and hypercholesterolemic rats administrated Vanillin are shown in
Table V. Hypercholesterolemic state was accompanied by a significant increase in total serum protein and globulin fraction but a slight increase was noticed in albumin fraction, followed by a remarkable decrease which nearly attained the initial level after administrating Vanillin. Also, hypercholesterolemia was accompained by significant decrease in Alb./Globulin (A/G) ratio. Feeding on Vanillin slightly increased the $A / G$ ratio but it still lower than the control group. The decrease in $A$ / $G$ ratio was due to nonsignificant increase in albumin biosynthesis in the liver. cells and /or the significant increase in the globulin concentration. The obtained results agreed with the results in Table VI which revealed a significant increase in catabolic products of protein as a result of hypercholesterolemic state, particularly uric acid and creatinine. Uric acid is often associated with the increase of nucleic acid synthesis and breakdown. In this respect administration of Vanillin at low and high doses exertes potent anabolic effects for protein metabolism. 


\section{REFERENCES}

1. Velican, C. M.- "Mechanism of cholesterol accumulation in arteriosclerotic lesions".- Rev. Rou. Med. Interne 9 (1972) 501.-515.

2. Hegested, D. M.; Mills, R. C.; Elvehjem, C. A. and Hart, E. B.- "Choline in nutrition of chicks".- J. Biol. Chem. 138 (1941) 459-964.

3. Campbell, J. A.- "Methodology of protein evaluation".- RAG Nutr. Document R. 101 add. 37, June meeting. New York (1961).

4. Abdel-Rahim, E. A.; El-Saadany, S. S. and Morgan, M. M."Biochemical dynamics of hypocholesterolemic action of Balanites aegyptiaca fruits".- Food Chem. 20 (1986) 69-78.

5. Knight, I. A.; Anderson, S. and Rawi, J. M.- "Chemical basis of sulphophosphovanilin reaction for estimating total serum lipid".- Clin. Chem. 18 (3) (1972) 199-205.

6. Chaurchami, A. I.; Miller, W. and Stein, I.O.B.- "Determination of total and free cholesterol".- Clin. Chem. 5 (1959) 609-614.

7. Fletcher, M. T.- "A colorimetric method for estimating serum triglycerides".- Clin. Chem. Acta. 22 (1968) 393-397.

8. Bartlett, G. R.- "Colorimetric assay methods for free and phosphorylated glyceric acids".- J. Biol. Chem. (1969) 234271.

9. Lee, Y. P. and Takabashi, T.- "An improved colorimetric determination of amino acids with the use of ninhydrin".Anal. Biochem. 14 (1966) 171-177.

10. Ritman, S. and Frankel, S.- "A colorimetric method for the determination of serum oxaloacetic and glutamic pyruvic transaminases".- Amer. J. Clin. Path. 28 (1957) 56-62.

11. King, P. R. N. and King, E. J.- "Determination of serum alkaline phosphatases".- J. Clin. Path. 7 (1954) 322.
12. Lowary, O. H.; Rosebrought, N. I.; Farr, A. L. and Randoll, R. J.- "Protein measurement with the folin phenol reagent".J. Biochem. 193 (1951) 265.

13. Peter, I.- "An improved method for determination of serum albumin and globulin".- Clin. Chem. 14 (1966) 194-247.

14. Caraway, W. T.- "Determination of serum uric acid".- Std. Method. Clin. Chem. 4 (1963) 239-247.

15. Chasson, A. L.; Cadry, H. I. and Stenly, M. A.- "Determination of serum creatininen.- Amer. J. Clin. Path. 35 (1961) 83.

16. Snedecor, G. W. and Cochran, W. G.- "Statistical methods".- (6th edn). lowa State Univ. Press, Amer., lowa, USA (1967) $393 \mathrm{pp}$

17. Boxer, L. A.; Grace, I. and Yokoyama, M.- "Correlation of B-lipoprotein levels and serum cholesterol concentration".Experimentie 27 (1971) 635-636.

18. Tawfic, R. E.- "The effect of nicotinic acid on cholesterol metabolism in rats".- M. Sc. Thesis. Biochem. College of Agric. Cairo. Univ. (1970).

19. Saied, M. M.- "Effect of some hypocholesterolemic agents on blood lipid pattern of white rats".- M. Sc. Thesis of Biochem. Fac. of Agric. Cairo. Univ. (1976).

20. El-Saadany, S. S.; Sitohy, M. Z.; Labib, S. M. and El-Massry, R. A.- "Biochemical dynamics and hypocholesterolemic action of Hibiscus sabadriffa (Karakde)".- Die Nahrung-Food. 35 (1991) 880-889.

21. El-Saadany, S. S.; El-Massry, R. A.; Labib, S. M. and Sitohy, M. Z.- "The biochemical role and hypocholesterolemic potential of Cassia fistula in hypercholesterolemic rats".Die Nahrung-Food 35 (1991) 807-816.

(Recibido: Febrero 1991) 